\title{
Antibacterial Effectiveness of Gading Kuning Coconut Extract (Cocos nucifera var. Eburnea) in Aeromonas hydrophila Bacteria In Vitro
}

\author{
Zakiyatul Fachiroh*, Irul Hidayati, Ita Ainun Jariyah \\ Program Studi Biologi, Fakultas Sains dan Teknologi, Universitas Islam Negeri Sunan Ampel, Surabaya 60237, \\ Indonesia \\ *Corresponding author: Fakhiroh15@gmail.com
}

\section{ABSTRACT}

Fish disease caused by Aeromonas hydrophila bacteria is very dangerous. These bacteria spread very quickly and result in a decrease in growth rates and can kill fish. To overcome this problem, fish cultivators usually use chemical drugs or antibiotics. However, the use of antibiotics can cause bacterial resistance and the presence of antibiotic residues in fish which can be harmful if the fish is consumed, so it is necessary to do other alternatives using traditional medicine. Yellow ivory coconut husk (Cocos nucifera var. Eburnea) is believed to have antibacterial properties. However, the content of potential secondary metabolites in these plants is not known, therefore this study aimed to determine the ability of the extract of the yellow ivory coconut husk (Cocos nucifera var. Eburnea) in inhibiting the growth of Aeromonas hydrophila bacteria. This study used a completely randomized design (CRD) with 6 treatments and 4 repetitions. The method used in this study is the disc diffusion method. The results of the disc diffusion method showed that the extract of ivory yellow coconut coir (Cocos nucifera var. Eburnea) was able to inhibit the growth of Aeromonas hydrophila bacteria. The concentration of coco coir extract of yellow ivory (Cocos nucifera var. Eburnea) $5000 \mathrm{ppm}$ had the highest inhibition zone value with an average of $12.225 \mathrm{~mm}$. Statistical test results show the value of Asymp. Sig of 0.004 which means $<0.05$. This indicates that the extract of the yellow ivory coconut husk (Cocos nucifera var. Eburnea) is able to inhibit the growth of Aeromonas hydrophila bacteria

Keywords: Antibacterial, Aeromonas hydrophila, Yellow ivory coconut husk (Cocos nucifera var. Eburnea), Zone of inhibition.

\section{ABSTRAK}

Penyakit ikan yang disebabkan oleh bakteri Aeromonas hydrophila sangat berbahaya. Bakteri ini menyebar sangat cepat dan mengakibatkan penurunan tingkat pertumbuhan serta mampu mematikan ikan. Untuk mengatasi masalah tersebut, biasanya para pembudidaya ikan menggunakan obat kimia atau antibiotik. Namun, penggunaan antibiotik dapat menyebabkan resistensi bakteri dan adanya residu antibiotik pada ikan yang dapat membahayakan jika ikan tersebut dikonsumsi, sehingga perlu dilakukan alternatif lain menggunakan pengobatan tradisional. Sabut kelapa gading kuning (Cocos nucifera var. Eburnea) diyakini memiliki sifat sebagai antibakteri. Namun, kandungan metabolit sekunder yang potensial pada tanaman tersebut belum diketahui, oleh karena itu penelitian ini bertujuan untuk mengetahui kemampuan ekstrak sabut kelapa gading kuning (Cocos nucifera var. Eburnea) dalam 
menghambat pertumbuhan bakteri Aeromonas hydrophila. Penelitian ini menggunakan Rancangan Acak Lengkap (RAL) dengan 6 perlakuan dan 4 pengulangan. Metode yang digunakan pada penelitian adalah metode difusi cakram. Hasil penelitian metode difusi cakram menunjukkan bahwa ekstrak sabut kelapa gading kuning (Cocos nucifera var. Eburnea) mampu menghambat pertumbuhan bakteri Aeromonas hydrophila. Konsentrasi ekstrak sabut kelapa gading kuning (Cocos nucifera var. Eburnea) 5000 ppm memiliki nilai zona hambat tertinggi dengan rata-rata sebesar 12,225 mm. Hasil uji statistik menunjukkan nilai Asymp. Sig sebesar 0,004 yang berarti < 0,05. Hal ini menunjukkan bahwa ekstrak sabut kelapa gading kuning (Cocos nucifera var. Eburnea) mampu menghambat pertumbuhan bakteri Aeromonas hydrophila.

Kata Kunci : Antibakteri, Aeromonas hydrophila, Sabut kelapa gading kuning (Cocos nucifera var. Eburnea), Zona hambat.

\section{PENDAHULUAN}

Indonesia merupakan negara kepulauan yang memiliki daerah perairan yang sangat luas. Sebanyak $70 \%$ wilayah negara Indonesia terdiri dari perairan, contohnya sungai, rawa, danau, telaga, tambak dan laut. Kekayaan alam yang dimiliki Indonesia ini dapat dimanfaatkan untuk pengembangan usaha dalam bidang perikanan [1].

Konsumsi ikan di Indonesia tahun 2019 sebesar 54,50 kg/kapita. Angka tersebut mengalami peningkatan dari tahun sebelumnya yaitu 50,69 kg/kapita. Pada tahun 2019 kementerian kelautan dan perikanan melakukan survei sementara tentang capaian angka konsumsi ikan nasional sebesar 55,95 $\mathrm{kg} / \mathrm{kapita} / \mathrm{tahun}$. Namun, menurut data realisasi sementara jumlah konsumsi ikan nasional melebihi target nasional tahun 2019 yakni sebesar 54,49 kg/kapita/tahun [2].

Jenis ikan tawar yang dikonsumsi adalah ikan nila, bandeng, lele, patin, mujair, bawal, gurami dan ikan mas. Namun kendala utama yang dapat menurunkan produksi, usaha budidaya, penurunan kualitas air dan bahkan kematian pada ikan yakni masalah penyakit ikan yang disebabkan oleh beberapa patogen seperti virus, bakteri, parasit, dan jamur. Salah satu indikator keberhasilan dalam usaha budidaya ikan yakni kondisi kesehatan ikan yang sangat mempengaruhi jumlah peningkatan hasil produksi. Penyakit yang sering dijumpai pada ikan adalah penyakit bercak merah atau Motile Aeromonas Septicema (MAS). Penyakit MAS sendiri disebabkan oleh invasi bakteri $A$. hydrophila. Bakteri ini merupakan bakteri normal yang ada di air tawar, namun adanya perubahan kondisi lingkungan seperti perubahan temperatur mengakibatkan bakteri menjadi patogen. Bakteri A. hydrophila bersifat patogen dan sangat berbahaya bagi kondisi ikan, bakteri ini menyebar sangat cepat dan dapat mengakibatkan penurunan tingkat pertumbuhan serta mampu mematikan ikan 80-100\% dalam waktu 1-2 minggu [3]. Penyebaran penyakit ini dapat terjadi karena kontak langsung pada ikan yang terinfeksi oleh bakteri A. hydrophila. Ciriciri gejala yang ditimbulkan jika ikan terinfeksi bakteri tersebut adalah kulit mudah terkelupas, adanya bercak merah pada seluruh tubuh, warna insang kebiruan atau pucat, exopthalmia (bola mata menonjol keluar), sirip punggung, sirip perut, sirip dada dan sirip ekor terlepas, terjadinya pendarahan pada anus, dan hilangnya nafsu makan [4].

Penyakit ikan ini muncul akibat ketidakserasian ikan sebagai inang patogen serta lingkungan. Sistem pertahanan tubuh ikan akan terganggu akibat adanya perubahan lingkungan dan perkembangan patogen pada wadah budidaya [5]. Penanganan penyakit ikan yang disebabkan oleh bakteri $A$. hydrophila dilakukan dengan menggunakan berbagai macam jenis antibiotik seperti oxytetracyclin, chloramphenicol, erythromycin, kanamycin dan rinfanicin. Akan tetapi penggunaan antibiotik dalam jangka waktu yang lama akan berdampak negatif yakni dapat menimbulkan bakteri resisten sehingga dilakukan alternatif lain dalam pengobatan penyakit dengan menggunakan bahan-bahan alami yang berasal dari tumbuhan [1], yang mengandung berbagai macam senyawa 
metabolit sekunder yang berpotensi sebagai antibakteri.

Komoditas kelapa di Indonesia sangat strategis dalam perekonomian. Produksi kelapa di Indonesia pada tahun 2018 mencapai 2.840.148 ton dan untuk wilayah Jawa timur sebanyak 244.060 ton [6]. Banyaknya permintaan kelapa di masyarakat mengakibatkan meningkatnya jumlah limbah dari kelapa seperti sabut kelapa. Adanya jumlah limbah sabut kelapa yang sangat banyak dapat dimanfaatkan untuk hal yang lebih berguna. Sabut kelapa mengandung senyawa metabolit sekunder yang dapat digunakan sebagai antibakteri. Menurut Silva et.,al (2013) ekstrak air sabut kelapa terdapat beberapa senyawa seperti asam elagat, asam galat, tanin, dan katekin. Kandungan tanin dan asam galat pada air sabut kelapa dapat digunakan untuk menghambat pertumbuhan bakteri Staphylococcus aureus. Selain itu, dapat dari penelitian sebelumnya juga dijelaskan bahwa ekstrak etanol 95\% sabut kelapa berbagai umur mulai dari yang kelapa muda, setengah tua, dan tua memiliki daya hambat terhadap bakteri Escherichia coli dan S. aureus. Sabut kelapa muda memiliki aktivitas antibakteri untuk bakteri E. coli dan $S$. aureus lebih besar dibanding sabut kelapa yang tua dan setengah tua [7]. Menurut Alkawi dkk (2021) buah kelapa gading kuning yang dibakar dapat digunakan sebagai obat alami untuk menyembuhkan penyakit jantung dan sebagai penawar racun. Selain itu kelapa gading kuning sering digunakan untuk obat batuk. Dari penelitian [8] diketahui bahwa infusum kulit batang kelapa gading kuning mampu menghambat pertumbuhan bakteri E. coli dan Candida albicans pada konsentrasi $37 \%$ v/v. Selain itu, secara fitokimia ekstrak air kulit batang kelapa gading kuning memiliki kandungan senyawa flavonoid, tanin dan kuinon [9].

Oleh karena itu, pada penelitian ini dilakukan uji efektivitas ekstrak sabut kelapa gading kuning sebagai antibakteri pada bakteri A. hydrophila dengan menggunakan metode difusi kertas cakram. Selain itu, penelitian ini juga bertujuan untuk mengetahui kandungan senyawa metabolit sekunder pada kelapa gading kuning yang mampu menghambat pertumbuhan bakteri A. hydrophila.

\section{METODE}

\section{Tempat Penelitian}

Penelitian dilakukan di Laboratorium Integrasi UIN Sunan Ampel Surabaya.

\begin{abstract}
Alat
Autoklaf, laminar air flow (LAF), jangka sorong, cawan petri, gelas beker, gelas ukur, mikropipet, erlenmeyer, batang pengaduk, oven, korek api, pinset, jarum ose, corong, vortex, neraca analitik, bunsen, tabung reaksi, aluminium foil, plastik, water bath, plastik wrap, kapas, lesung, ayakan, spreader, kertas saring whatman, rotary evaporator, inkubator, pipet tetes.
\end{abstract}

\section{Bahan}

Sabut kelapa gading kuning muda, etanol 96\%, biakan bakteri A. hydrophila, kertas cakram (paper disk), media Tryptic Soy Agar (TSA), akuades, antibiotik chlorampenicol, alkohol $75 \%$, larutan $\mathrm{HCL}$, serbuk $\mathrm{Mg}, \mathrm{H}_{2} \mathrm{SO}_{4}$, air panas, $\mathrm{FeCl} 1 \%, \mathrm{NaCl} 0,9 \%, \mathrm{CH}_{3} \mathrm{COOH}$ glasial, $\mathrm{HCl} 2 \mathrm{~N}$, barium klorida $(\mathrm{BaCl})$.

\section{Pengambilan dan Persiapan Sampel}

Sabut kelapa gading kuning yang digunakan dalam penelitian ini diambil di kecamatan Tanggulangin, Sidoarjo, Jawa timur dalam keadaan segar. Sabut kelapa yang diambil berumur sekitar 4-6 bulan (kelapa muda).

\section{Proses Ekstraksi}

Sabut kelapa gading kuning dicuci dengan air mengalir kemudian dipotong-potong kecil selanjutnya dikeringkan dengan oven pada suhu $50^{\circ} \mathrm{C}$. Setelah kering sabut kelapa dihaluskan dengan penggilingan/lesung. Sabut kelapa yang sudah halus diayak menggunakan ayakan 60 mesh dan ditimbang 300 gram. Kemudian sampel diekstraksi dengan metode maserasi dengan merendam serbuk sabut kelapa dengan etanol 96\% sebanyak 6 Liter selama 72 jam pada suhu ruangan dan tidak terkena cahaya matahari langsung dan sesekali dilakukan pengadukan. Kemudian hasil dari maserasi disaring menggunakan kertas saring whatman untuk memisahkan filtratnya. Filtratnya kemudian diuapkan menggunakan rotary evaporator untuk 
memisahkan pelarutnya pada suhu $50^{\circ} \mathrm{C}$ dengan kecepatan $200 \mathrm{rpm}$ selama \pm 30 menit hingga mendapatkan ekstrak yang kental. Ekstrak kental yang diperoleh kemudian dipekatkan dengan penangas air (Water bath) agar seluruh pelarutnya habis dan diperoleh ekstrak yang kering/pekat. Kemudian dilakukan perhitungan rendemen ekstrak sabut gading kuning. Rendemen ekstrak dihitung dengan rumus :

Rendemen $=\frac{\text { bobot total ekstrak }}{\text { berat bubuk simplisia total }} \times 100 \%$

\section{Uji Fitokimia}

Dilakukan uji skrining fitokimia terhadap sabut kelapa gading kuning untuk mengetahui kandungan senyawa metabolit sekunder seperti flavonoid, tanin, terpenoid, alkaloid, saponin, fenol dan steroid.

\section{Uji Flavonoid}

Disiapkan ekstrak sabut kelapa sebanyak 2 ml, kemudian ditambahkan larutan $\mathrm{FeCl}_{3}$ 1\% (1 gr $\mathrm{FeCl}_{3}$ dalam $100 \mathrm{ml}$ aquades). Jika sampel berubah menjadi warna hijau, merah, hitam pekat, biru atau ungu menandakan jika sampel positif mengandung flavonoid [10].

\section{Uji Terpenoid}

Disiapkan ekstrak sabut kelapa sebanyak 2 ml, kemudian ditambahkan 3 tetes HCL pekat dan 1 tetes $\mathrm{H}_{2} \mathrm{~S}_{4}$ pekat. Jika warna berubah menjadi jingga atau ungu kecoklatan menandakan jika sampel positif terpenoid. Sedangkan jika warna berubah menjadi merah dan ungu menandakan positif mengandung senyawa terpenoid [11].

\section{Uji Tanin}

Disiapkan ekstrak sabut kelapa lalu ditambahkan beberapa tetes larutan $\mathrm{FeCl}_{3} \quad 1 \%$ jika warna berubah menjadi hijau kehitaman, atau biru tua, atau kehitaman menandakan sampel positif mengandung senyawa tanin [12].

\section{Uji Saponin}

Disiapkan ekstrak sabut kelapa sebanyak 2$3 \mathrm{ml}$ lalu ditambahkan $10 \mathrm{ml}$ air panas dan didinginkan. Campuran dikocok secara vertikal dengan kuat selama 10 detik. Lalu ditambahkan
1 tetes HCL $2 \mathrm{~N}$. Jika tebentuk buih yang stabil setinggi $1-10 \mathrm{~cm}$ selama tidak kurang dari 10 menit maka sampel tersebut positif mengandung saponin [13].

\section{Uji Alkaloid}

Disiapkan ekstrak sabut kelapa sebanyak 2 ml lalu ditambahkan asam klorida. Jika terbentuk endapan berwarna coklat atau jingga pada bagian dasar tabung reaksi menandakan sampel positif mengandung alkaloid [14].

\section{Uji Fenol}

Disiapkan ekstrak sabut kelapa lalu ditambahkan beberapa tetes larutan $\mathrm{FeCl}_{3} \quad 1 \%$ sebanyak 10 tetes. Jika berubah warna menjadi hijau, merah, hitam pekat, biru atau ungu menandakan positif mengandung fenol [14].

\section{Uji Steroid}

Disiapkan ekstrak sabut kelapa sebanyak 2 $\mathrm{ml}$, lalu ditambahkan $\mathrm{CH}_{3} \mathrm{COOH}$ glasial sebanyak 10 tetes dan $\mathrm{H}_{2} \mathrm{SO}_{4}$ pekat sebanyak 2 tetes, kemudian dikocok perlahan dan dibiarkan selama beberapa menit. Jika berubah warna biru atau hijau maka positif mengandung senyawa steroid [14].

\section{Pengujian Antibakteri}

Isolat bakteri $A$. hydrophila diperoleh dari koleksi Laboratorium Universitas Airlangga. Bakteri A. hydrophila diambil 1 ose dan ditanam pada media cair tryptic soy agar (TSA) sebanyak $10 \mathrm{ml}$ kemudian diinkubasi selama 24 jam pada suhu $27^{\circ} \mathrm{C}$. Setelah itu, dilakukan pembuatan larutan standar McFarland 0,5 (setara dengan $1,5 \times 10^{8} \mathrm{CFU} / \mathrm{ml}$ ). Suspensi bakteri $A$. hydrophila sebanyak $100 \mu \mathrm{l}$ kemudian dituangkan pada media TSA dan diratakan dengan menggunakan spreader lalu dibiarkan selama 30 menit [15]. Uji efektivitas antibakteri secara in vitro menggunakan metode difusi agar dilakukan dengan berbagai variasi konsentrasi ekstrak yakni 500, 1000. 2000, dan 5000 ppm, untuk kontrol positif menggunakan chloramphenicol sedangkan kontrol negatif menggunakan aquades. Metode difusi ini menggunakan kertas cakram $6 \mathrm{~mm}$ yang telah ditetesi dengan ekstrak sabut kelapa sebanyak 50 $\mu \mathrm{l}$ kemudian diletakkan pada media TSA yang sudah ditumbuhi bakteri $A$. hydrophila dengan 4 
kali pengulangan [16] Selanjutnya, diinkubasi pada suhu $27^{\circ} \mathrm{C}$ selama 24 jam dan dilakukan pengukuran diameter daerah hambatan sekitar kertas cakram dengan menggunakan jangka sorong (mm).

\section{Analisis Data}

Data hasil penelitian berupa zona hambat dianalisis menggunakan uji Kruskall-Wallis dan uji Mann-Whitney untuk mengetahui data konsentrasi yang memiliki perbedaan paling signifikan

\section{HASIL}

Filtrat hasil maserasi dari ekstrak sabut kelapa gading kuning muda yang kering atau pekat sebanyak 63,54 gram. Rendemen ekstrak etanol 96\% sabut kelapa gading kuning adalah $21,18 \%$ dari 300 gram sabut gading kuning. Uji fitokimia ekstrak etanol $96 \%$ sabut kelapa gading kuning ini bertujuan untuk mengetahui golongan senyawa dan komponen bioaktif yang terkandung pada sabut kelapa gading kuning secara kualitatif yang berpotensi memberikan aktivitas antibakteri. Hasil uji fitokimia dapat dilihat pada tabel 1 .

Hasil uji fitokimia pada Tabel 1 menjelaskan bahwa ekstrak sabut kelapa gading kuning positif mengandung senyawa metabolit sekunder flavonoid, tanin dan fenol dan menunjukkkan hasil negatif terhadap senyawa steroid, alkaloid, terpenoid, dan saponin.

Tabel 1 Hasil Uji Fitokimia Ekstrak Sabut Kelapa gading kuning (Cocos nucifera var. Eburnea)

\begin{tabular}{|c|c|c|c|}
\hline $\begin{array}{l}\text { Uji } \\
\text { Fitokimia }\end{array}$ & $\begin{array}{l}\text { Warna } \\
\text { Kontrol }\end{array}$ & $\begin{array}{l}\text { Warna } \\
\text { Hasil }\end{array}$ & Hasil \\
\hline Flavonoid & $\begin{array}{l}\text { Orange } \\
\text { keruh }\end{array}$ & Hitam & + \\
\hline Tanin & $\begin{array}{l}\text { Orange } \\
\text { keruh }\end{array}$ & Hitam & + \\
\hline Fenol & $\begin{array}{l}\text { Orange } \\
\text { keruh }\end{array}$ & Hitam & + \\
\hline Steroid & $\begin{array}{c}\text { Orange } \\
\text { keruh }\end{array}$ & $\begin{array}{l}\text { Orange } \\
\text { kuning }\end{array}$ & - \\
\hline Alkaloid & $\begin{array}{c}\text { Orange } \\
\text { keruh }\end{array}$ & $\begin{array}{l}\text { Orange } \\
\text { keruh }\end{array}$ & - \\
\hline Terpenoid & $\begin{array}{c}\text { Orange } \\
\text { keruh }\end{array}$ & $\begin{array}{l}\text { Kuning } \\
\text { bening }\end{array}$ & - \\
\hline Saponin & $\begin{array}{c}\text { Orange } \\
\text { keruh }\end{array}$ & $\begin{array}{c}\text { Tanpa } \\
\text { buih }\end{array}$ & - \\
\hline
\end{tabular}

Keterangan :

(+) Terdapat kandungan senyawa

(-) Tidak terdapat kandungan senyawa

Hasil daya hambat ekstrak sabut kelapa gading kuning pada bakteri $A$. hydrophila dapat dilihat pada Tabel 2.

Tabel 2 Hasil uji daya hambat ekstrak sabut kelapa

\begin{tabular}{ccccccc}
\hline \multirow{2}{*}{ Ulangan } & \multicolumn{7}{c}{ Konsentrasi } \\
\cline { 2 - 7 } & $\mathbf{K}(+)$ & $\mathbf{K}(-)$ & $\mathbf{5 0 0 0} \mathbf{~ p p m}$ & $\mathbf{2 0 0 0} \mathbf{~ p p m}$ & $\mathbf{1 0 0 0} \mathbf{~ p p m}$ & $\mathbf{5 0 0} \mathbf{~ p p m}$ \\
\hline $\mathbf{1}$ & 22,1 & 7,7 & 10,7 & 9,9 & 9,9 & 9,2 \\
$\mathbf{2}$ & 21,5 & 7,1 & 13,6 & 13,9 & 10,7 & 10,5 \\
$\mathbf{3}$ & 22,6 & 7,7 & 15,5 & 10,5 & 8,3 & 10,5 \\
$\mathbf{4}$ & 20 & 7,7 & 9,1 & 11,6 & 11,9 & 8,3 \\
\hline Rata-Rata & 21,55 & 7,55 & 12,225 & 11,475 & 10,2 & 9,625 \\
\hline
\end{tabular}

Dilihat pada tabel 2, hasil uji daya hambat ekstrak sabut kelapa gading kuning memiliki zona hambat yang bervariasi. Dari hasil nilai rata-rata zona hambat terlihat bahwa semakin tinggi konsentrasi maka semakin besar nilai zona hambat.

Dari hasil data uji statistik didapatkan data tidak berdistribusi normal karena nilai $\mathrm{P}$ sebesar 0,001. Dan pada ada uji kruskal-wallis didapatkan nilai Asymp, sig sebesar 0,004.

\section{PEMBAHASAN}

Hasil rendemen yang dihasilkan sama dengan penelitian sebelumnya menurut Sumarni dkk. (2019) menyatakan hasil rendemen ekstrak etanol 96\% sabut kelapa (Cocos nucifera Linn) muda sebesar $12,43 \%$ dari 250 gram sabut kelapa. Jumlah rendemen yang tinggi menandakan jika jumlah ekstrak yang dihasilkan 
semakin banyak. Nilai rendemen yang tinggi juga menunjukkan semakin banyak komponen senyawa aktif yang terkandung ekstrak [17]. Banyaknya rendemen yang dihasilkan disebabkan karena waktu perendaman selama $3 \times 24$ jam. Waktu ekstraksi yang lama akan menghasilkan rendemen yang lebih besar karena terpenuhinya waktu kontak antara pelarut untuk berinteraksi dengan zat yang akan diekstrak [18].

Hasil uji fitokimia pada ekstrak sabut kelapa gading kuning sama dengan hasil penelitian [7] yang menyatakan bahwa ekstrak etanol 96\% sabut kelapa muda, setengah tua dan tua mengandung senyawa tanin, fenol dan flavonoid, tetapi tidak mengandung kelompok senyawa alkaloid dan steroid.

Hasil zona hambat yang diperoleh ekstrak sabut kelapa gading kuning sama dengan hasil penelitian Dalimunthe dkk. (2006) yang menyatakan bahwa ekstrak sabut kelapa (Cocos nucifera) terhadap bakteri E. coli dan Shigella dysentriae dan menurut Wulandari (2018) bahwa ekstrak etanol sabut kelapa (Cocos nucifera Linn) terhadap bakteri $E$. coli dan $S$. aureus memiliki nilai zona hambat paling besar pada konsentrasi yang tinggi. Dari penelitian ini dijelaskan bahwa sabut kelapa gading kuning mampu menghambat bakteri $A$. hydrophila yang belum ada pada penelitian terdahulu dengan zona hambat tertinggi yakni pada konsentrasi $5000 \mathrm{ppm}$ dimana memiliki nilai rata-rata zona hambat sebasar 12, $225 \mathrm{~mm}$. Menurut Ajizah (2004) jika semakin tinggi konsentrasi semakin sedikit jumlah bakteri yang mampu bertahan hidup. Semakin besar ekstrak yang diberikan, maka semakin besar diameter hambatan pertumbuhan bakteri, hal ini menunjukkan bahwa semakin banyak kadar zat berkhasiat sebagai antibakteri yang terkandung dalam ekstrak tersebut. Nilai rata-rata zona hambat ekstrak sabut kelapa gading kuning terhadap pertumbuhan bakteri A. hydrophila. Jika dibandingkan kontrol negatif dan kontrol positif serta beberapa konsentrasi. Konsentrasi ekstrak sabut kelapa gading kuning memiliki nilai ratarata zona hambat yang lebih kecil dibandingkan dengan kontrol positif (chloramphenicol). Hal ini karena chloramphenicol merupakan antibiotik spektrum luas yang efektif terhadap beberapa jenis bakteri dan kuman aerob.
Chloramphenicol adalah antibiotik yang mempunyai aktivitas bakteriostatik dan pada dosis tinggi bersifat bakterisidal, aktivitas antibiotik chloramphenicol mampu menghambat sintesis protein bakteri, bagian yang dihambat adalah enzim peptidil transferase yang berperan sebagai katalisator untuk ikatan peptida pada proses sintesis bakteri. Sedangkan jika dilihat dari hasil penelitian ini rata-rata zona hambat pada kontrol negatif (akuades) sebesar 7,55 mm atau dikategorikan tingkat sensifitasnya rendah. Adanya zona hambat pada kontrol negatif ini tidak bisa dikatakan sebagai zona hambat karena akuades tidak memiliki sifat antibakteri. Zona bening yang terlihat disebabkan oleh teknik sebaran yang tidak rata sehingga koloni bakteri tidak tersebar rata pada media [19].

Menurut Oktarina dkk. (2017) kategori tingkat sensitifitas antibakteri apabila kriteria tingkat sensifitas kekuatan diameter zona hambat $<6 \mathrm{~mm}$ (tidak memiliki zona hambat), zona hambat 6-9 $\mathrm{mm}$ dikategorikan tingkat sensifitasnya rendah, zona hambat 9-12 $\mathrm{mm}$ dikategorikan tingkat sensifitasnya sedang dan zona hambat $>12 \mathrm{~mm}$ dikategorikan tingkat sensifitasnya tinggi. Maka dilihat dari hasil nilai rata-rata zona hambat, konsentrasi 5000 ppm memiliki tingkat sensifitasnya tinggi, konsentrasi 2000 ppm dan konsentrasi 1000 ppm dikategorikan tingkat sensifitasnya sedang dan konsentrasi 500 ppm dikategorikan tingkat sensifitasnya rendah.

Dari hasil data uji statistik didapatkan data tidak berdistribusi normal karena nilai $P$ sebesar 0,001 yang menunjukkan jika nilai tersebut $<0,05$ dari taraf signifikansi yang telah ditentukan. Karena data tidak berdistribusi normal maka di lanjutkan ke uji kruskal-wallis. Pada uji kruskal-wallis didapatkan nilai Asymp, sig sebesar 0,004 yang berarti $<0,05$ dari taraf signifikansi. Hal ini menunjukkan bahwa data tersebut terdapat perbedaan dalam proses menghambat bakteri A. hydrophila dari 4 konsentrasi, kontrol positif dan kontrol negatif. Maka hipotesis awal atau Ha diterima sehingga dari ekstrak sabut kelapa gading kuning mampu menghambat pertumbuhan bakteri $A$. hydrophila.

Ekstrak etanol 96\% sabut kelapa gading kuning mampu menghambat bakteri $A$. hydrophila yang merupakan bakteri gram 
negatif. Menurut Dewi (2010) bakteri gram negatif memiliki peptidoglikan yang sangat tipis, kandungan lipid yang banyak, membran terluar menyerupai bilayer yang memiliki fungsi untuk pertahanan secara selektif senyawa-senyawa yang masuk atau keluar sel dan mengakibatkan efek toksik. Membran terluar dari bakteri terdiri dari lipopolisakarida yang tersusun dari lipid A dan fosfolipid dengan sifat nonpolar..

Ekstrak sabut kelapa gading kuning mampu menghambat bakteri A. hydrophila karena bakteri tersebut memiliki peptidoglikan yang tipis sehingga dengan mudah dirusak oleh kandungan zat antibakteri seperti tanin, flavonoid dan fenol yang ada pada ekstrak sabut kelapa gading kuning.

Senyawa tanin memiliki kemampuan sebagai antibakteri dengan cara mengaktifkan adhesi sel mikroba serta mengaktifkan enzim dan mengganggu metabolisme transport protein pada lapisan sel bagian dalam. Senyawa tanin juga dapat mengganggu kinerja polipeptida dinding sel. Hal ini mampu menyebabkan terganggunya pembentukan dinding sel dan mampu menyebabkan sel bakteri pecah karena terjadi tekanan osmotik dan fisik serta mampu menyebabkan kematian pada bakteri [20]. Menurut Lisan (2015) penentuan jenis tanin secara kualitatif dan penentapan kadar tanin dari sabut kelapa secara permanganometri menyatakan untuk mendapatkan kadar tanin yang lebih tinggi sebaiknya menggunakan sabut kelapa muda. Sabut kelapa muda menghasilkan tanin sebesar 5,62\% dibandingkan dengan sabut kelapa tua yakni $4,28 \%$. Dari hasil tersebut menyatakan bahwa secara uji kualitatif sabut kelapa muda dan kelapa tua mengandung tanin yang terkondensasi. Kandungan tanin yang ada pada sabut kelapa memiliki sifat fungsional yakni sebagai pengendap protein, dan antioksidan. Selama ini tanin juga memiliki manfaat sebagai pengawet kayu, adsorben logam berat, obat-obatan dan antimikroba. Tanin merupakan astrigen jalur usus yang dapat mengurangi sekresi cairan dalam usus sehingga kadar air dalam kotoran manusia berkurang dan dapat mencegah mencret [21].

Senyawa flavonoid mampu sebagai antibakteri yakni dapat menggumpalkan protein yang ada di ribosom. Protein merupakan zat makanan berupa asam amino yang berfungsi sebagai pembangun dan pengatur bagi tubuh bakteri, memiliki peran dalam proses interkalasi atau ikatan hidrogen dengan menumpuk basa asam nukleat yang selanjutnya mampu menggumpalkan protein dan menghambat proses pembentukan DNA dan RNA. Kemampuan flavonoid dalam merusak membran sel karena flavonoid memiliki sifat lipofilik terhadap dinding sel, yang mana nantinya mampu merusak lapisan lipid pada bakteri dengan membentuk ikatan kompleks dengan dinding sel sehingga mengakibatkan kerusakan membran sel [22].

Senyawa fenol mampu sebagai antibakteri karena senyawa fenol mempunyai kemampuan mendenaturasi protein dan mengganggu fungsi membran sel sebagai lapisan yang selektif dan menyebabkan sel lisis, dengan mekanismenya membentuk ikatan kompleks dengan membran plasma sehingga membran plasma yang selektif akan mengalami kebocoran. Selain itu, senyawa fenol mempunyai kemampuan melakukan imigrasi dari fase cair ke fase lipid yang ada pada membran sel bakteri dan menyebabkan turunnya kemampuan permukaan membran sel [23]. Dilihat dari hasil uji fitokimia ekstrak sabut kelapa memiliki kemampuan sebagai antibakteri karena senyawa turunan dari fenol seperti asam fenolat, flavonoid dan tanin kuat sebagai antibakteri.

\section{KESIMPULAN}

Golongan senyawa metabolit sekunder yang terdapat pada ekstrak sabut kelapa gading kuning adalah tanin, fenol dan flavonoid. Pemberian variasi konsentrasi ekstrak sabut kelapa gading kuning dapat mempengaruhi diameter zona hambat, dimana semakin tinggi ekstrak sabut kelapa maka semakin besar juga zona hambat yang dihasilkan. Ekstrak sabut kelapa gading kuning memiliki daya hambat tertinggi terhadap bakteri A. hydrophila pada konsentrasi $5000 \mathrm{ppm}$ dengan rata-rata zona hambat sebesar 12, $225 \mathrm{~mm}$. 


\section{DAFTAR PUSTAKA}

[1] Sumayani K., Rahayu., dan C. Yudi. 2008. Daya Hambat Rimpang Lengkuas (Alpinia galangal) dengan Kosentrasi Berbeda Terhadap Pertumbuhan Aeromonas hydrophila Secara in vitro. Jurnal Berkalah Ilmiah Vol.3(1).

[2] Kementrian Kelautan dan Perikanan. 2021. Kementrian Kelautan dan Perikanan(Online). URL https://kkp.go.id/artikel/16451-2020-kkp

[3] Cipriano, R.C. 2001. Aeromonas hydrophila and Motil Aeromonas Septicemia of Fish. United States Departement of the Interior Fish and Wild Life Service Division of Fisheries Research, Washington DC, $25 \mathrm{pp}$.

[4] Mulia D. S. 2003. Pengaruh Vaksin Debris Sel Aeromonas hydrophila dengan Kombinasi Cara Vaksinasi dan Booster Terhadap Respon Imun dan $\mathrm{Ti}$ Perlindungan Relatif Pada Lele Dumbo (Clarias gariepinus Burchell). Tesis Universitas Gajah Mada Yogyakarta.

[5] Ashari C., Reiny A T., dan Magdalena E. F. K. 2014. Diagnosa Penyakit Bakterial Pada Ikan Nila (Oreochromis niloticus) Yang Di Budidaya Pada Jaring Tancap Di Danau Tondano. Jurnal Budidaya Perairan Vol.3(24).

[6] Kementerian pertanian. 2018. Produksi Kelapa Menurut Provinsi di Indonesia tahun 2016-2020. Pertanian.go.id.

[7] Wulandari A. 2018. Aktivitas Antibakteri Ektrak Etanol Sabut Kelapa (Coccus nucifera Linn) Pada Berbagai Tingkat Ketuaan. Jurnal Kovalen Vol.4(3).

[8] Nuraini, Ani. 2011. Uji Aktivitas Antimikroba Infusum Ekstrak Kulit Batang Kelapa (Cocos Nucifera var.eburnea) Skripsi Program Studi Farmasi STIKES Bakti Tunas Husada Tasikmalaya.

[9] Fitriady, Ari. 2011. Skrining Fitokimia Ekstrak Air Kulit Batang Kelapa dan Pemanfaatanya Sebagai Serbuk Minuman Kesehatan. Skripsi Tasikmalaya: Program Studi Farmasi STIKes Bakti Tunas Husada.
[10] Agustina. Eva. 2017. Uji Aktivitas Senyawa Antioksidan dari Ekstrak Daun Tin (Ficus carica Linn) Dengan Pelarut Air, Methanol dan Campuran MetanolAir. Klorofil. Vol.1(1) : 38-47.

[11] Septyaningsih, D. 2010. Isolasi dan Identifikasi Komponen Utama Ekstrak Biji Buah Merah (Pandanus Conoidenus lamk). Universitas Sebelas Maret. Surakarta.

[12] Utami, S. U. 2014. Uji aktivitas Antibakteri Fraksi Etil Asetat, KloroformPetroleum Eter, dan N-Heksan Hasil Hidrolisis Ektrak Methanol MikroalgaChlorella sp. UIN Malang, Malang.

[13] Depkes RI. 1995. Farmakope Indonesia. Departemen Kesehatan Republik Indonesia. Jakarta.

[14] Harborne, J. B. 1987. Metode Fitokimia Terjemahan Padmawinata, K dan Soediro, I. Institut Teknolog Bandung. Bandung.

[15] Sinurat Afti A.P., Person P.R., dan Nurlaila E. H. 2019. Uji Aktivitas Antibakteri Ekstrak Metanol Rumput Laut Gracilaria edulis Terhaap Bakteri Aeromonas hydrophila. Jurnal Enggano Vol.4(1):105-114.

[16] Sari, Endang T.P., Tri Gunaedi dan Ervina Indrayani. 2017. Pengendalian Infeksi Bakteri Aeromonas hydrophila Pada Ikan Nila (Oreochromis niloticus) Dengan Ekstrak Rimpang Lengkuas Merah (Alpinia purpurata). Jurnal Biologi Papua Vol.9 (2) : 37-42.

[17] Dewatisari, W. F., Rumiyanti, L., and Rakhmawati, I. 2018. Rendemen Dan Skrining Fitokimia Pada Ekstrak Daun Sanseviera Sp. Jurnal Penelitian Pertanian terapan Vol.17(3) : 97-202,

[18] Sumarni Ni Ketut., Rahmawati., Syamsuddin dan Ruslan. 2019. Daya Hambat Ekstrak Etanol Sabut Kelapa (Cocos nucifera Linn) Terhadap Pertumbuhan Staphylococcus aureus dan Escherichia coli Pada Tahu. Jurnal Kimia Mulawarman. Vol.17(1) : 45-51.

[19] Allo Maranty, B R. 2016. Uji Aktivitas Antibakteri Dari Ekstrak Air Kulit Buah Pisang Ambon Lumut (Musa Acuminata Colla) Terhadap Pertumbuhan 
Staphylococcus aureus. Skripsi Fakultas Keguruan Dan Ilmu Pendidikan Universitas Sanata Dharma Yogyakarta.

[20] Sari,F.P. S.M.Sari. 2011. Ekstraksi Zat Aktif Antimikroba dari Tanaman Yodium (Jatropha multifida Linn) Sebagai Bahan Baku Alternatif Antibiotik Alami. Skripsi. Fakultas Teknik Universitas Diponegoro.

[21] Ismarani. 2012. Potensi senyawa tanin dalam menunjang produksi ramah lingkungan. Jurnal Agribisnis dan Pengembangan Wilayah. Vol.3(2) : 46-55.

[22] Sabir A. 2005. In vitro antibacterial activity of flavonoids Trigona sp. propolist against Streptococcus mutans. Dental Journal Vol.38 : 135-141.

[23] Rahayu, WP. 2000. Aktivitas Antimikroba Bumbu Masakan Tradisional Hasil Olahan Industri terhadap Bakteri Pathogen, Buletin Teknologi dan Industri Pangan Vol. XI (2) : 42- 48. 